\title{
THE IMPORTANCE OF BUILDING POSITIVE REPUTATION OF CHEMICAL INDUSTRY COMPANIES FOR DEVELOPMENT OF REATIONSHIPS WITHIN SUPPLY CHAINS
}

\author{
Martina Jelinkova ${ }^{1}$, Hana Lostakova ${ }^{2}$ \\ Department of Economy and Management of Chemical and Food Industry, Faculty of Chemical Technology, \\ University of Pardubice, Studentská 95, Pardubice, Czech Republic \\ E-mails: ${ }^{1}$ martina.jelinkova@upce.cz (corresponding author); ${ }^{2}$ hana.lostakova@upce.cz
}

\begin{abstract}
Recent surveys on the B2B market in the Czech Republic show clearly that most of the addressed managers consider reputation as the most important factor of the competitiveness of their companies. Therefore, it is possible to regard mastered reputation management as the basis for creation of a unique competitive advantage, which finally results in deepening of the positive relationships with all the stakeholders. The paper presents the outcomes of primary quantitative surveys conducted within chemical product supply chains on the B2B market in the Czech Republic. The surveys aimed to identify factors that are crucial for building positive reputation of companies within supply chains and, at the same time, to assess and compare their importance as perceived by chemical product suppliers and their customers.
\end{abstract}

Keywords: corporate reputation, corporate image, B2B markets, Czech Republic, chemical industry; relationships within supply chains.

JEL Classification: L14; L65; M31.

\section{Introduction}

In the process of creating and delivering value, they are important not only well-functioning material, information and financial flows but also the processes and activities that enhance the emotional and social benefits of customers and have positive impact on the value of the relationship (Branska et al. 2012).

The surveys conducted recently on the $\mathrm{B} 2 \mathrm{~B}$ market in the Czech Republic (Hyrslova et al. 2015) clearly show that reputation, i.e. a good name of the company, is considered by most of the addressed managers as the most significant factor of the competitiveness of their companies and an important criterion which they consider in supplier selection (Pecinova et al. 2015). Therefore, it is obvious that the level and the reputation of the supplier will play a key role for strengthening the supplier-customer relations. Some authors (e.g. Brown et al. 2006) even assert that the company reputation is, within the buyer-supplier relationship, sometimes even more important than mutual confidence. There is empirical evidence of the fact that there is a significant link between the reputation of the supplier and the buyer's confidence, which affects the extent to which the B2B buyer tries to develop the relationship with his/her supplier and to which he/she invests into its future. The aim is also to obtain sufficient amount of relevant information to get effective marketing orienta- tion on a particular uncovered segment, not only from the point of view of the sellers' offer, but primarily from the point of view of the perception of the offer by the customer (Vlckova et al. 2014).

Therefore, the corporate reputation can be considered as one of the most significant aspects for creation and deepening of mutual relations on B2B markets. This has also been confirmed by our research, whose outcomes are presented below.

\section{Relation between corporate reputation and image on B2B markets}

\subsection{Definition of corporate reputation}

On the basis of probably the oldest in the literature cited concepts of Selnes (1993) and Fombrun (1996), it is possible to view corporate reputation as perception of the overall attractiveness of the company as compared to the competitors. Fombrun (1996) develops hid definition of corporate reputation as follows: "reputation of a company is how both its past activities and the future prospects are perceived, which demonstrates the overall attractiveness of the company in all its main segments as compared to the other leading competitors". Corporate reputation is here understood both as perception of the past activities and the future prospects of the company, and also from the subjective point of view as the attractiveness of the company (Money et al. 2010). In accordance with

\footnotetext{
(C) 2016 The Authors. Published by VGTU Press. This is an open-access article distributed under the terms of the Creative Commons Attribution License (CC-BY 4.0), which permits unrestricted use, distribution, and reproduction in any medium, provided the original author and source are credited.
} 
the concept of Fombrun (1996), corporate reputation is also defined by Brown et al. (2006). They see it as mental association relating to the company, which stakeholders associate with the company. Similarly, Keh and Xie (2009) also state that scientists view corporate reputation either prom the economic point of view, where they perceive it as expectations and perception of the internal and/or external public towards the specific corporate attributes, or from the point of view of the relation towards an institution, where they perceive corporate reputation as a global (overall) image reflecting perception by all the involved groups - e.g. customers, employees, investors, etc. (e.g. Deephouse 2000).

To summarize it, it is possible to declare that corporate reputation has partly rational (i.e. actual comparison with the competitors, actual or declared behaviour of the company on the market, etc.), but also affective (i.e. individual perception, motivation, liking or antipathy, etc.) aspects, which often play a very important, but hardly affectable, role. Therefore, it is obvious that each entity can see the reputation of the given company from another point of view. Nevertheless, from the market point of view reputation is understood as the overall (global) perception of the company on the market across all the involved parties. So, corporate reputation can be considered as the overall evaluation of the company saying whether the company is basically "good" or "bad" (e.g. Roberts, Dowling 2002). The thing is what the market thinks of the company, and so it is possible to consider it as information verified by the market - a company cannot have a good reputation if the marked does not think so and vice versa (Hansen et al. 2008).

\subsection{Definition of corporate image}

The term corporate reputation is closely connected with the term "corporate image". Both terms are often perceived in the literature almost as synonyms, and the difference between the definitions of corporate reputation and image disappears to a certain extent. In spite of that, some authors indicate that both terms do not mean the same. E.g. Svoboda (2006) states: "Image is a broad term subject to more frequent changes, while reputation represents a good name built on a long-term basis, and it is nowadays more important for relationships between organizations and the other stakeholders". If we pay out attention to "image" only, Svoboda (2006) offers the following relatively comprehensive general definition: "Image connects all the ideas of a public individual or group of a certain subject matter of opinion, which can be entities or objects like persons (personal image, politician's image, businessman's image, etc.), countries or cities (image of a country, nation, or city), institutions and organizations (e.g. municipalities, groups and associations, political parties), and companies with activities intended for the public (corporate, product image, brand image, package image, promotional image)". Specification of corporate image receives relatively broad attention in the professional literature, where we can find, for example, the following definitions:

- Veber (2000) says that corporate image is how it is perceived by the public, i.e. what is the company's image, picture and projection in the eyes of its employees and particularly its business partners (investors, suppliers, customers, etc.).

- Smith (2000) declares that corporate image is the state of perception. In his opinion, it is the sum of the public feelings in relation to the given organization resulting from use of products, customer care, business environment, and corporate communication.

- Kotler (2000) states that corporate image refers to the set of opinions, ideas, and impressions a person creates about a company or a product.

- Foret (2013) understands corporate image as an idea each individual makes of a company both on the basis of his/her personal experience, and particularly on the basis of communications and information received from other persons or from the media.

The definitions outlined above imply that the concepts of corporate reputation and corporate image are identical in many respects.

\subsection{Mutual links and differences between cor- porate reputation and corporate image}

When comparing definitions of image and reputation, it is possible to come to a conclusion that both concepts overlap in many ways - in both cases it is about perception of the activity and behaviour of the company on the market, which is affected by the past, current experience, and also by the expected future prospects. In both cases, origination of both image and reputation involves affective components, and both result in creation of certain attitudes towards the company, and these attitudes also include, apart from the emotions, a cognitive (empirical) and conative (i.e. the way the attitude we have influences how we act or behave) components. The fundamental difference between these 
two terms is particularly seen in the weight of the experience, in long-termedness and flexibility. We believe that reputation can be considered as a longer term concept than image, particularly as a result of drawing on longer term experience with the company's operation on the market. In accordance with our experience, reputation draws more on the history, from which the business partners deduce the behaviour of the company in the future. On the other hand, image is rather considered as the matter of the "current" status, which can be better influenced even in a shorter (compared to reputation) time horizon. Corporate image can be better affected by the current actions and innovations in the areas of products, services, customer care, PR, or a change in the corporate design. A company can be perceived as "innovative", "responsive", but the fact whether it will actually enjoy a "good" reputation among its business partners or not will only be obvious on the basis of longer term experience and confidence in maintaining the positive direction in the future. This proposition is also supported by the statement by Henry Ford, who said (Brown et al. 2010): "You can't build a reputation on what you are going to do". Therefore, it is obvious that building a successful reputation, but also a brand image on the B2B market, requires care and time. However, an interesting aspect of corporate reputation is the fact that while its successful building requires a very long time horizon, it can be damaged very quickly. The paradox is that, as some surveys show (e.g. Rhee, Haunschild 2006), if a company with a good reputation has a problem, it often suffers more than those with a bad reputation. The thing is that if a company makes a mistake, it can have an adverse effect as a result of disappointment caused by high expectations. From this point of view, we believe that image can be considered as more stable, apparently also as a result of the fact that reputation directly affects the experience of the business partners, whereas image is mostly affected by the perception of the general public and the other stakeholders, where the negative aspects of functioning of business relations might get later and not to such a significant extent. This particularly holds true on B2B markets, where reputation is important for business relations, while image is rather reflected in relations with the public and the other stakeholders.

\section{Building and benefits of positive corporate reputation}

Obviously, image and reputation affect each other. We believe that it is not possible to build a good corporate reputation without a positive image, and vice versa. In view of the fact that image can obviously be affected more directly, for building a positive reputation it is possible to recommend focusing attention mainly to those attributes which result in a positive image, products and services, social behaviour and responsibility (Tetrevova, Svedik 2012), environment and communication. Most authors also agree that one of the most important tools for systematic building, and if need be changing, of image and thus also reputation is a so-called corporate identity. It is seen by some authors (e.g. Smith 2000) as a "visual way of identification of the given company, society, or organization, which uses all the means of contact with the public". However, in this concept the term "corporate identity" almost merged with the term "corporate design". This certainly is not right. Corporate identity is a lot wider term and reflects both the history of the company and the corporate visions, or its ethical values (Svoboda 2006). This is also supported by Foret (2011), who declares that corporate identity with good prospects should be based on long-term experience and traditions of the institution, on its system of values and principles, on the atmosphere in the institution, on the topics and ways of communication. Probably the most apposite definition of corporate identity has been formulated by Bedrnova and Novy (2002) (Vysekalova, Mikes 2009), who understand it as a purposefully created strategic concept of the internal structure, operation, and external presentation of a particular company in the market environment. Among its elements, they count corporate communication, corporate design, and corporate practice. Veber (2000) completes these corporate identity attributes with corporate culture and product (i.e. the design of the own product).

By goal-directed influencing of the above specified components of the corporate identity on an individual basis, it is possible to build up the desired corporate positioning and to create a content and formal basis for creation of a positive image and thus also a corporate reputation. A good reputation is then established by exertion of longterm influence of the positive image on the market partners, where the basic elements of this phenomenon are deepened. These elements include (Svoboda 2006): credibility; reliability; trustworthiness, and awareness of responsibility.

The built-up positive corporate image and reputation represent a number of benefits for the company. If we summarize the opinions of individual authors (Keh, Xie 2009; Pelsmacker 2003; 
Smith 2000; Nemec 1999), the main benefits of a positive image and a good reputation can be seen in:

- Current product sales support - a positive image of the manufacturer and his/her good reputation increases the value of the products perceived by the customers and, at the same time, increase the benefits, but also decrease the costs perceived by the customers in relation to the purchase.

- Possibility of achieving higher product prices accepted by the customers - positive corporate image and reputation add a value to the brand, and so it is possible, in certain cases and particularly on highly uncertain markets, to achieve higher prices of the offered products.

- Support and facilitation of launching new products on the market - positive corporate image and reputation support development of new and innovated products, as they create a favourable platform for their launch on the market.

- Possibility of acquiring a cost advantage positive corporate image and reputation help the company to acquire a cost advantage over the competitors as a result of decreasing contractual and controlling costs with their suppliers and a potential lower pace of growth of the employees' salaries. Positive corporate image and reputation also often result in the fact that the company can achieve lower marketing costs and, thanks to the higher negotiation power, often obtain lower purchase prices.

- Strengthening of relations with investors and support of investments - positive image and reputation help to acquire higher quality and more investments from investors thanks to the fact that they remind the influential players on financial markets of the existence of the company.

- Building of a positive atmosphere in the company and increasing the employees' efforts - positive image and reputation increase the good feeling of the employees, support the pride and identification of the employees with the company, and motivate the employees to increase the efficiency and performance.

- Increase in the attractiveness of the company on the labour market - positive image and reputation strengthen the company's ability to attract (and retain) the best people, who represent a strategic asset on the current hypercompetitive markets.
- Strengthening of the influence on the other stakeholders and the public - positive corporate image and reputation support strengthening of the engagement and loyalty of all the groups of the stakeholders (Money et al. 2010). As Bajcan (2003) declares: "Positive opinions of the public, or the media, help the given entity to be more successful in a particular area of business, create some kind of an intangible comparative advantage over the other competitors, and make it easier for the entity to promote its opinions and attitudes. And also, it prepares a very favourable field for next steps relating to quality marketing planning".

- Prevention of crises or better crisis management - positive corporate image and reputation can be understood as an account from which it is possible to draw when the times are bad, when the company with a good reputation can benefit, e.g. from the presumption of innocence. In hard periods, a good name excludes or limits occurrence of problems in relation to pressure groups and consumer organizations.

The above specified benefits make it obvious that well-mastered management of creation of the current image and the resulting long-term reputation is the basis of a hardly copyable competitive advantage, which finally results in deepening of positive relations with all the stakeholders.

\section{Reputation study models}

If we wanted to study corporate reputation in more detail, we would find, in the world literature, a number of models, which analyze corporate reputation from different points of view. These models aim to find a certain system how to evaluate, compare, and even measure corporate reputation. In view of the fact that each of the models approaches corporate reputation from a little different point of view, it is possible to recommend them in different situations. E. g. Fombrun (1996) indicates that it is possible to study corporate reputation from different points of view, which, according to the author, include: perception of the working environment in the organization, products and services, financial performance, and emotional attractiveness. It is obvious that this model can be used with advantage for enhancement of the corporate reputation from the point of view of the functional elements of the organization, such as human resources, marketing, and finance. On the other hand, Davies et al. (2015) state that corporate reputation can be meas- 
ured on the basis of the fact how the stakeholders perceive the "personality" of the organization. Within this approach, the stakeholders are asked to assess the organization as a personalized whole. In this case, corporate reputation is assessed on the basis of the fact whether the organization is perceived as e.g. elegant, dominant, or amiable. This model will be useful within the process of researching the basic personality characteristics with which the perceived reputation can be connected, which is the most modern trend in creation of the desired brand positioning. In our case, where we are trying to identify the role the reputation plays in the supplier-customer relations on B2B markets, it would definitely be the most suitable to use the model published by MacMillan et al. (2005). The given model is based on the fact that corporate reputation can be evaluated from the point of view of various aspects of the stakeholders' experience, which they acquire within their contact with the company (Money et al. 2010). Selected experience from supplier-customer relations was researched and assessed in more detail within our research, whose outcomes are presented below.

\section{Primary research into the importance of individual factors affecting the perceived reputation of manufacturers within supply chains of chemical companies}

\subsection{Primary research specification}

The primary quantitative research into the importance of individual factors affecting the perceived reputation of the suppliers of chemical products was conducted by the Department of Economy and Management of the Chemical and Food Industries, the Faculty of Chemical Technology, the University of Pardubice, in 2013-2015. The research was performed on the B2B market only, at first among the suppliers and subsequently among the purchasers of chemical products.

The first phase of the research was based on personal questioning using a network of trained questioners. The respondents were employees of large industrial suppliers of chemical raw materials in the Czech Republic, specifically the top managers of the companies, the staff of sales departments, customer service departments, employees involved in strategic development, research and development, the staff of economic departments, but also selected employees from manufacturing, purchase, and product quality control departments. The research involved 41 respondents in total.
The second phase of the research was dedicated to identification of the opinions concerning the researched problems from the point of view of the buyers of the final products of the suppliers involved in the first phase of the research. The primary research into the customers was conducted through a network of questioners using the method of both electronic and personal questioning. The data was gathered from 40 customers in total.

The research was conducted, in both phases, on the basis of questionnaires, where the respondents were asked to evaluate the beneficial effects of individual selected attributes showing the level and reputation of the supplier for development of supplier-customer relations. The assessment was performed using a 7-point scale, where 1 referred to the evaluation of the factor as "absolutely without benefits" and 7 corresponded to the evaluation as "absolutely beneficial". The research outcomes were subsequently statistically processed separately from the point of view of the suppliers' opinions, and separately also from the point of view of the customers. The suppliers' and the customers' perceptions were finally compared and the differences between the perception of the suppliers of chemical products and their purchaser were analyzed.

\subsection{Processing and analysis of research outcomes}

As already mentioned, the first phase of the research was conducted by personal interviews in supply companies. Using a factor analysis, the results obtained allowed specifying three factors that play a role in developing relations between the supplier and the customer in terms of quality and prestige of the supply company from the perspective of suppliers. They are:

- Level of technological advancement and reputation of the supplier;

- Reputation and image of the supplier;

- Tradition of the supplier.

Statistical processing of the results of research is demonstrated in detail in Table 1.

Table 1 clearly shows that in strengthening relationships with customers, suppliers consider all the characteristics examined to be important. The results show that the perception of the interviewees is clearly dominated by a view that it is long-term positive experience of the customer with the supplier that contribute most to the strengthening of relations between suppliers and customers (median 
Table 1. Perceiving the benefits of attributes of the overall supplier quality and reputation from the perspective of customers (Source: made by authors)

\begin{tabular}{|c|c|c|c|c|c|c|c|c|c|c|c|}
\hline \multirow{3}{*}{$\begin{array}{c}\text { Supplier quality } \\
\text { and reputation } \\
\text { factor }\end{array}$} & \multirow{3}{*}{$\begin{array}{l}\text { Characteristics of Supplier quality } \\
\text { and reputation }\end{array}$} & \multicolumn{10}{|c|}{ Benefits from the perspective of suppliers } \\
\hline & & \multicolumn{7}{|c|}{$\begin{array}{c}\text { Relative frequency of the usefulness } \\
\text { levels (in percent) }\end{array}$} & \multirow{2}{*}{ 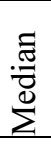 } & \multirow{2}{*}{$\stackrel{n}{ٍ}$} & \multirow{2}{*}{$\stackrel{\mathbb{E}}{\stackrel{\Xi}{\infty}}$} \\
\hline & & 1 & 2 & 3 & 4 & 5 & 6 & 7 & & & \\
\hline \multirow{3}{*}{$\begin{array}{l}\text { Level of techno- } \\
\text { logical advance- } \\
\text { ment and reputa- } \\
\text { tion of the } \\
\text { supplier }\end{array}$} & High technical quality of supplied products & 2 & 0 & 2 & 5 & 15 & 38 & 38 & 6 & 6 & 5.6 \\
\hline & $\begin{array}{l}\text { High level of mastery of technological pro- } \\
\text { cesses in the company }\end{array}$ & 3 & 6 & 0 & 17 & 48 & 17 & 9 & 6 & 6 & 5.3 \\
\hline & $\begin{array}{l}\text { Overall quality of the company and positive } \\
\text { reputation in the industry }\end{array}$ & 2 & 0 & 7 & 15 & 33 & 38 & 5 & 5 & 6 & 5.5 \\
\hline \multirow{2}{*}{$\begin{array}{l}\text { Reputation and } \\
\text { image of the } \\
\text { supplier }\end{array}$} & $\begin{array}{l}\text { Long-term positive experience of the cus- } \\
\text { tomer with the company }\end{array}$ & 2 & 0 & 2 & 5 & 18 & 40 & 33 & 6 & 7 & 5.9 \\
\hline & $\begin{array}{l}\text { Quality of customer base - services to major } \\
\text { players in the industry }\end{array}$ & 3 & 6 & 0 & 17 & 48 & 17 & 9 & 5 & 6 & 5.4 \\
\hline $\begin{array}{l}\text { Tradition of the } \\
\text { supplier }\end{array}$ & $\begin{array}{l}\text { Long tradition of the company as a manufac- } \\
\text { turer of products }\end{array}$ & 2 & 5 & 10 & 12 & 43 & 23 & 5 & 6 & 6 & 5.4 \\
\hline
\end{tabular}

Note: The scale from 1 - completely useless to 7 - entirely beneficial.

6, modus 7, average 5.9). This aspect clearly confirms the basic premise of our research that longterm positive reputation of the supplier stemming from long-term positive experience will play a key role in the supplier-customer relationship.

Other characteristics assessed by the suppliers are evaluated almost equally in the perception of their usefulness for strengthening relationships with customers and most respondents perceive them as rather or very beneficial. The only characteristic worth mentioning is perhaps the "High level of mastery of technological processes in the company", which has the lowest average rating of 5.3. We believe that suppliers perceive there a high level of mastery of technological processes in the company as an essential prerequisite for quality customer service, which they believe the customer perceives as part of services, not evaluating it too separately. However, the results show that this characteristic is also considered important by the suppliers of chemical products, and it is rather important in the development of relationships between suppliers and customers.

Using a factor analysis, the second part of the research, which examined the perception of usefulness of characteristics of the overall quality and reputation of the supplier for developing customersupplier relationship from the perspective of customers, proved the existence of very similar factors as in the research into perception from the perspective of suppliers. The difference was in the correlation of the attribute Overall quality of the company and positive reputation in the industry where it correlated in the consumers with the factor Tradition of the supplier, while in the suppliers it correlated more with the Level of technological advancement of the supplier. In the perception of customers, the following factors play a role in strengthening their relations with suppliers, in particular:

- Reputation and image of the supplier;

- Technological advancement of the supplier;

- Tradition and reputation of the supplier.

Results of the second part of the research are demonstrated in detail in Table 2.

As shown in Table, the customers also consider all the identified factors speaking about the quality and reputation of the supplying company to be important for strengthening relationships with suppliers. In mutual comparison of the importance of individual characteristics of the supplier's reputation for customers, we find that there are two characteristics that are the most beneficial for customers, namely the high technical quality of the products and the long-term positive experience of the customer with the company (median 6 , mode 6 , mean almost 6). It is logical that the high technical quality of products supplied is a priority to the customers, as it ensures a trouble-free use thereof. Also, long-term positive experience with the supplier, which are the basis of its good reputation, form a foundation stone of mutually beneficial suppliercustomer relationships.

Interestingly, the beneficial effect of the attribute "Overall quality of the company and positive reputation in the industry", which is certainly directly related to the reputation of the company, did not appear at the forefront in the customer evaluation. The reason can probably be found in 
Table 2. Perceiving the benefits of attributes of the overall supplier quality and reputation from the perspective of suppliers (Source: made by authors)

\begin{tabular}{|c|c|c|c|c|c|c|c|c|c|c|c|}
\hline \multirow{3}{*}{$\begin{array}{l}\text { Supplier quality and } \\
\text { reputation factor }\end{array}$} & \multirow{3}{*}{$\begin{array}{c}\text { Characteristics of supplier quality and } \\
\text { reputation }\end{array}$} & \multicolumn{10}{|c|}{ Benefits from the Perspective of Suppliers } \\
\hline & & \multicolumn{7}{|c|}{$\begin{array}{l}\text { Relative frequency of the useful- } \\
\text { ness levels (in percent) }\end{array}$} & \multirow{2}{*}{ 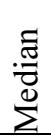 } & \multirow{2}{*}{$\frac{n}{2}$} & \multirow{2}{*}{ 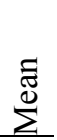 } \\
\hline & & 1 & 2 & 3 & 4 & 5 & 6 & 7 & & & \\
\hline \multirow{2}{*}{$\begin{array}{l}\text { Reputation and image } \\
\text { of the supplier }\end{array}$} & $\begin{array}{l}\text { Long-term positive experience of the } \\
\text { customer with the company }\end{array}$ & 2 & 0 & 2 & 3 & 20 & 35 & 38 & 6 & 6 & 5.8 \\
\hline & $\begin{array}{l}\text { Quality of customer base - services to } \\
\text { major players in the industry }\end{array}$ & 0 & 3 & 3 & 18 & 16 & 47 & 13 & 5 & 5 & 4.9 \\
\hline \multirow{2}{*}{$\begin{array}{l}\text { Level of technologi- } \\
\text { cal advancement of } \\
\text { the supplier }\end{array}$} & $\begin{array}{l}\text { High technical quality of supplied } \\
\text { products }\end{array}$ & 0 & 2 & 5 & 10 & 15 & 50 & 18 & 6 & 6 & 5.9 \\
\hline & $\begin{array}{l}\text { High level of mastery of technological } \\
\text { processes in the company }\end{array}$ & 3 & 0 & 0 & 21 & 26 & 40 & 10 & 6 & 6 & 5.5 \\
\hline \multirow{2}{*}{$\begin{array}{l}\text { Tradition and reputa- } \\
\text { tion of the supplier }\end{array}$} & $\begin{array}{l}\text { Overall quality of the company and } \\
\text { positive reputation in the industry }\end{array}$ & 0 & 2 & 2 & 5 & 33 & 43 & 15 & 5 & 6 & 5.1 \\
\hline & $\begin{array}{l}\text { Long tradition of the company as a } \\
\text { manufacturer of products }\end{array}$ & 0 & 5 & 5 & 17 & 17 & 33 & 23 & 5 & 5 & 4.8 \\
\hline
\end{tabular}

Note: The scale from 1 - completely useless to 7 - entirely beneficial.

the weight of personal experience, which is the most important in terms of the mutual trust of business partners, and therefore customers do not attach such importance to general reputation of the supplier in the industry in strengthening long-term relationships.

The research has shown that attributes "Quality of customer base - services to major players in the industry" and "Long tradition of the company as a manufacturer of products" (median 5, modus 5 , mean almost 5), are perceived as rather beneficial for building the corporate reputation of the supplier, from the perspective of customers. We believe that customers do not definitely consider services to major players in the industry and the long tradition of the company as a manufacturer of products to be a guarantee of high quality of the supplied product and a problem-free relationship. Nevertheless, they evaluate both attributes as rather beneficial for building mutual relations.

The processed results showed that in the perception of the benefits of individual characteristics, referring to the quality and reputation of the supplier, in the development of the customer-supplier relationships there are some differences between the perceptions of suppliers and customers. Statistical significance of the differences was analyzed using Pearson's chi-square test and exact nonparametric median test by a Monte Carlo method. The tests demonstrated statistically significant differences between suppliers and buyers in the perception of benefits of two characteristics of the quality and reputation of the supplier, which are:
- Quality of customer base - services to major players in the industry (Pearson chisquare test, Monte Carlo sig. $=0.013$; Median test, Asymp. Sig. $=0.005$ ).

- Long tradition of the company as a manufacturer of products (Pearson chi-square test, Monte Carlo sig. $=0.060$; Median test, Asymp. Sig. = 0.022).

As for the other characteristics of the quality and reputation of the supplier, no statistically significant difference was found between the perception of their usefulness for building long-term relationships between customers and suppliers.

The differences observed in the two characteristics mentioned above were further analyzed in detail. The following Figure 1 provides a comparison of views of suppliers and customers related to perception of the benefits of the indicator "Quality of customer base - services to major players in the industry".

Figure 1 shows that the largest number of suppliers ( 47 percent) sees this factor as very beneficial, while the majority of customers (49 percent) see it as rather beneficial. A little higher perceived level of the beneficial effect of the quality of customer base from the perspective of suppliers than that of consumers might be due to the fact that suppliers attach too much importance to what impact the services to major companies in the industry have on improving the company's image in the eyes of customers. It is obvious that this factor is not extremely important to the customers, but it is nevertheless necessary to pay attention to it, as the 


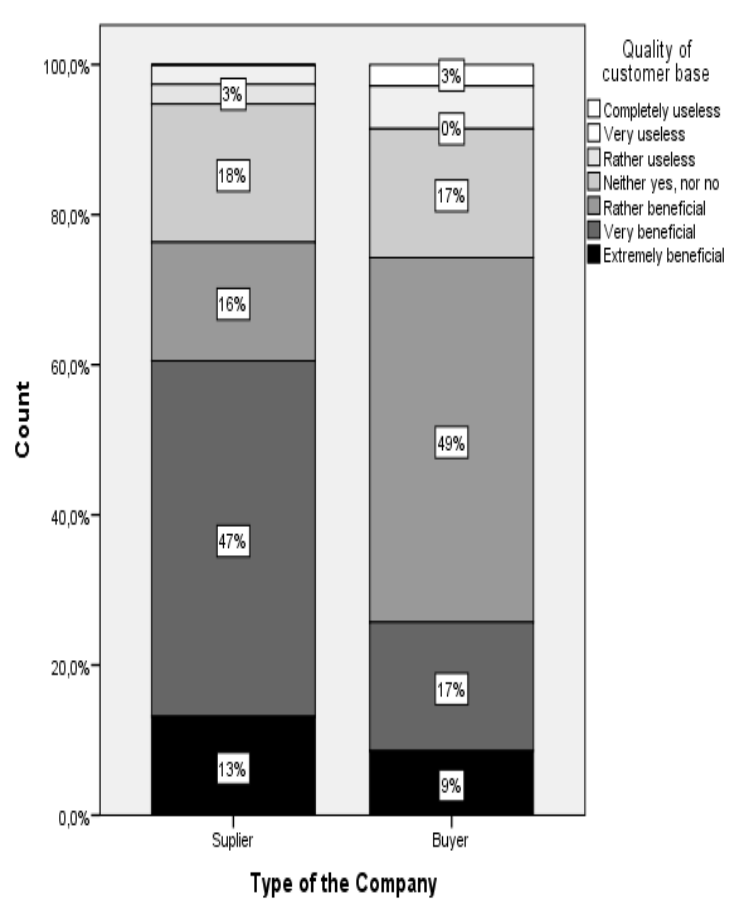

Fig. 1. Perceiving the benefits of the attribute "Quality of customer base - services to major players in the industry" from the perspective of customers and from the perspective of their suppliers (Source: made by authors)

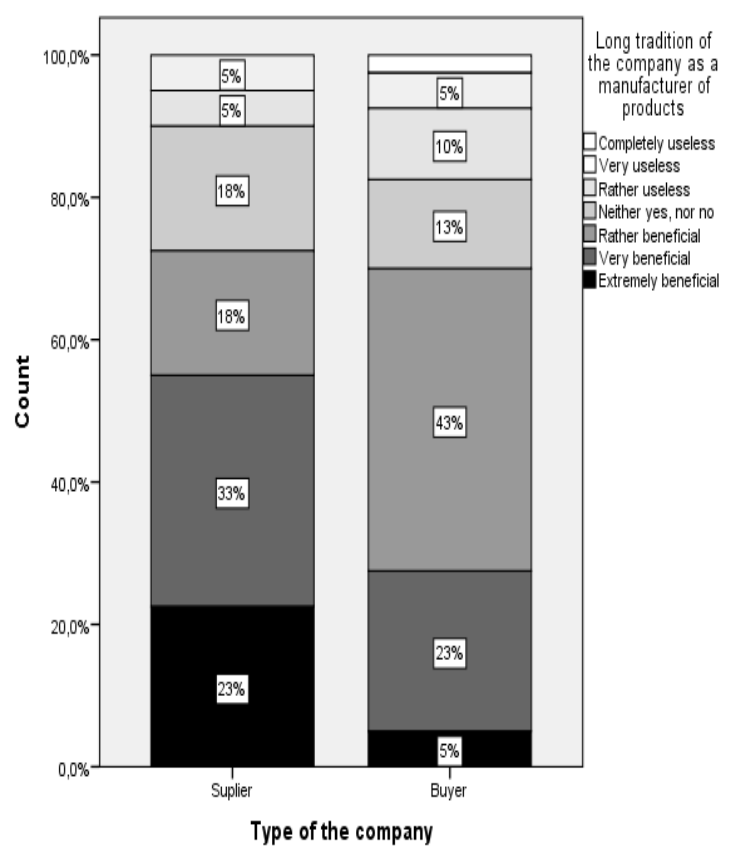

Fig. 2. Perceiving the benefits of the attribute "Long tradition of the company as a manufacturer of products"

from the perspective of customers and from the perspective of their suppliers (Source: made by authors) customers perceive this aspect as rather beneficial for building long-term relationships, thus it is of a certain benefit to them.

An analysis of statistical differences between the perceptions of suppliers and customers in terms of the attribute "Long tradition of the company as a manufacturer of products" is shown in Figure 2.

It can be read in Figure 2 that the suppliers mainly view it as a very ( 33 percent) to extremely (23 percent) beneficial attribute for developing relationships with customers, while the customers perceive this attribute for the most part only as rather beneficial (43 percent). In the perception of the suppliers, this factor is thus viewed as somewhat more important than from the perspective of the customers for the development of mutual relations. This may be due to the fact that the suppliers consider their long experience in producing the product to be a guarantee of quality product, which the consumers do not perceive as decidedly.

\section{Conclusions}

Literary sources as well as research confirm that a positive reputation as a long-term positive perception of the company in the market proved by experience and deep-rooted in the market is an impossible-to-copy competitive advantage, which plays a vital role in the customer choice. This applies to the consumer, but especially to the industrial markets, where relationships of business partners tend to be deeper, more immediate and more important in choosing a supplier. A positive reputation of the supplier then certainly boosts the customer's confidence especially at the beginning of the relationship, but it also strengthens the belief that the relationship will continue without problems, which is a great advantage for a stable functioning of the industrial enterprise.

Our research, conducted in 2013-2015, clearly shows that in terms of strengthening and developing mutual relations between the suppliers and the customers there are three factors that play an important role, which are almost identical from the perspective of suppliers and customers. These include:

- Reputation and image of the supplier;

- Technological advancement of the supplier;

- Tradition and reputation of the supplier in the industry.

Some differences were diagnosed between perceptions of suppliers and customers only in the perception of benefits for the development of mutual relations in two sub-level characteristics of the quality and reputation of the supplier, namely 
"Quality of customer base - services to the major players in the industry" and "Long tradition of the company as a manufacturer of products". These sub-characteristics demonstrated a certain overestimation of their importance for the development of supplier-customer relations on the part of the suppliers. It can be stated that all the observed characteristics of the overall quality and reputation of the supply company are, from the perspective of both suppliers and customers, evaluated as important for the development of mutual relations, differences were found only in the degree of the perceived importance. Therefore, it is necessary to pay much attention to all the aspects explored in the development of customer-supplier relationships.

In conclusion, it is necessary to add that the outcomes were acquired through a research conducted only in the selected branches of business among the key purchasers of the respective product categories. Although the research involved the branches of business typical for the chemical industry, it would be suitable, in order to obtain representative research outcomes, to perform another research into other chemical product categories involving a significantly larger sample group of respondents, which we intend to do in the following years.

\section{Disclosure Statement}

We do not have any competing financial, professional, or personal interests from other parties.

\section{References}

Bajcan, R. 2003. Techniky public relations. Praha: Management Press.

Bedrnova, E.; Novy, I. 2002. Psychologie a sociologie rizeni. Praha: Management Press.

Branska, L.; Pecinova, Z.; Lostakova, H. 2012. Modification of Packaging Management in a Company as a Result of Involvement in a Value Network, in $21^{\text {st }}$ International Conference on Metallurgy and Materials “METAL 2012”, 23-25 May 2012, Brno, Czech Republic.

Brown, T. J.; Dacin, P. A.; Pratt, M. G.; Whetten, D. A. 2006. Identity, intended image, construed image, and reputation: an interdisciplinary framework and suggested terminology, Journal of the Academy of Marketing Science 34(2): 99-106. http://dx.doi.org/10.1177/0092070305284969

Brown, T. J.; Dacin, P. A.; Pitt, L. F. 2010. Corporate image and reputation in B2B markets: insights from CI/ARG 2008, Journal of Industrial Marketing Management 39(2): 709-711.

http://dx.doi.org/10.1016/j.indmarman.2010.02.008
Davies, G.; Chun, R.; Da Silva, R. V.; Ropers, S. 2015. Corporate reputation and competitiveness. London: Routledge.

Deephouse, D. L. 2000. Media reputation as a strategic resource: an integration of mass communication and resource-based theories, Journal of Management 26(6): 1091-1112.

http://dx.doi.org/10.1177/014920630002600602

Fombrun, C. J. 1996. Reputation: realizing value from the corporate image. Boston: Harvard Business School Press.

Foret, M. 2013. Marketing communication in public administration. Brno: ASTRON studio CZ.

Foret, M. 2011. Marketingova komunikace: legislativa, systemy, metody, praxe. Brno: Computer Press.

Hansen, H.; Samuelsen, B. M.; Silseth, P. R. 2008. Customer perceived value in B-t-B service relationships: investigating the importance of corporate reputation, Journal of Industrial Marketing Management 37(2): 206-217. http://dx.doi.org/10.1016/j.indmarman.2006.09.001

Hyrslova, J.; Vnouckova, L.; Hajek, M. 2015.Koncepce udrzitelneho rozvoje a konkurenceschopnost podniku chemickeho prumyslu, Chemicke listy 109(4): 319-326.

Keh, H. T.; Xie, Z. 2009. Corporate reputation and customer behavioral intentions: the roles of trust, identification and commitment, Journal of Industrial Marketing Management 38(7): 732-742. http://dx.doi.org/10.1016/j.indmarman.2008.02.005

Kotler, P. 2000. Marketing podle Kotlera. Praha: Management Press.

MacMillan, K.; Money, K.; Downing, S.; Hillenbrand, C. 2005. Reputation in relationships: measuring experiences, emotions and behaviors, Corporate Reputation Review 8(3): 214-232. http://dx.doi.org/10.1057/palgrave.crr.1540251

Money, K.; Hillenbrand, C.; Day, M.; Magnan, G. M. 2010. Exploring reputation of B2B partnerships: extending the study of reputation from the perception of single firms to the perception of inter-firm partnerships, Journal of Industrial Marketing Managemnet 39(5): 761-768.

http://dx.doi.org/10.1016/j.indmarman.2010.02.015

Nemec, P. 1999. Public relations: komunikace $v$ konfliktnich a krizovych situacich. Praha: Management Press.

Pecinova, Z.; Stehnova, M.; Lostakova, H. 2015. Evaluation of suppliers by customers as a way to increase business performance, in Proceedings from $2^{\text {nd }}$ International Multidisciplinary Scientific Conference on social sciences \& arts "SGEM 2015", 26.8.-1.9. 2015. Albena, Bulgaria.

Pelsmacker, P. 2003. Marketingova komunikace. Praha: Grada Publishing.

Rhee, M.; Haunschild, P. 2006. The liability of good reputation: a study of product recalls in the U. S. Automobile Industry, Organization Science 17(1): 101-117. http://dx.doi.org/10.1287/orsc.1050.0175 
Roberts, P. W.; Dowling, G. R. 2002. Corporate reputation and sustained superior financial performance, Journal of Strategic Management 23(12): 10771093. http://dx.doi.org/10.1002/smj.274

Selnes, F. 1993. An examination of the effect of product performance on brand reputation, satisfaction and loyalty, European Journal of Marketing 27(9): 1935. http://dx.doi.org/10.1108/03090569310043179

Smith, P. 2000. Moderní marketing. Praha: Computer Press.

Svoboda V. 2006. Public relations moderne a ucinne. Praha: Grada Publishing.
Tetrevova, L.; Svedik, J. 2012. Gambling industry and corporate social responsibility - the Czech experience, WSEAS Transactions on Business and Economics 9(2): 116-125.

Veber, J. 2000. Management: zaklady, prosperita, globalizace. Praha: Management Press.

Vlckova, V.; Lostakova, H.; Patak, M. 2014. Selected problems arising within cluster analysis usage for market segmentation, in $23^{\text {rd }}$ International Conference on Metallurgy and Materials "Metal 2014", 21-23 May 2014, Brno, Czech Republic.

Vysekalova, J.; Mikes, J. 2009. Image a firemni identita: zaklady, prosperita, globalizace. Praha: Grada. 